\title{
Impact of COVID-19 on Food Systems and Rural Livelihoods in Malawi
}

\section{COVID-19 Country Report - September 2020}

Prepared by Mirriam Matita and Masautso Chimombo

\section{Introduction}

Given the ravaging effects of the COVID-19 pandemic worldwide, this study seeks to estimate its likely impact on food systems and livelihoods in Malawi. This briefing note is based on our stratified random sample of 114 household heads (32 female and 82 male) drawn from an APRA household survey of groundnut producers in Mchinji and Ntchisi districts, Central Region, as well as seven key informant interviews from those areas. The APRA COVID-19 data collection will be carried out over three rounds. This report presents insights obtained from the first round of research conducted during June/July 2020.

\section{Context}

Following the start of the COVID-19 pandemic, the Government of Malawi took preemptive action and declared a state of emergency on 20 March 2020 and closed schools three days later. The first cases of COVID-19 were confirmed on 2 April and the government introduced new regulations on 7 April in an attempt to contain the virus. The first attempt at a national lockdown was challenged in court and was never fully implemented due to the absence of measures to support vulnerable and poor people, especially in the informal sector in urban areas. Amidst this, Malawi held court-ordered presidential elections on 23 June. During the campaign period, many people failed to adhere to crowd control measures to prevent the spread of COVID-19.

As of 30 August, Malawi had conducted 44,511 tests, of which 5,536 cases were confirmed. There were, at this time, 2,215 active cases, 3,147 recoveries and 174 deaths. Schools are set to re-open in early September in phases, beginning with examination classes. There has been a general decline in economic activities in response to the crisis.

\section{"This year farmers have sold their produce at very} low prices. Influx of produce traders to this area has heavily reduced." - Extension coordinator (Chikwatula EPA, Ntchisi)

\section{Health and disease}

Awareness of COVID-19 was widespread among all respondents. Reported incidences of the virus remained low. While half of respondents said they had heard of confirmed cases of COVID-19, only $4 \%$ knew of cases in their villages and $10 \%$ had a diagnosed case in their own household. Close to $94 \%$ stated that they could access health care at the nearest health post.

\section{Response to threat of COVID-19}

With the closure of schools, only $28 \%$ of children were doing schoolwork at home. Half of all children were doing more

\section{Key findings}

- $\quad$ There was widespread awareness about COVID-19 among respondents.

- Most children were not doing any schoolwork at home, but more house and farm work; whilst one in every three children were sitting idle in the absence of school.

- $\quad$ Girls were doing more housework relative to boys; whilst the reverse is true for paid work away from home.

- One in three households reported receiving no government support to help them cope with the crisis.

- There had been a decline in business enterprises, but not in most farming activities.

- Access to off-farm work since COVID began was limited, especially outside the village.

- There had been an increase in the cost of transport of farm produce, as well as a significant decline in the number of traders coming to villages.

- Already-stressed households reported facing food and nutrition insecurity, with over a third reporting spending a whole day without food.

- Food prices and availability in local markets remained largely unchanged.

- However, households reported a rising cost of living since the start of the crisis; and a subjective assessment of the poverty situation showed increasing destitution.

household chores, girls more so than boys. A third of children were involved in more farm work, both boys and girls. Paid work away from home was found to be more common for boys than girls. However, it was reported that one in every three children was idle.

COVID-19 regulations had led to a general reduction in movements within and outside the villages, affecting trade and employment opportunities. About $69 \%$ of respondents had received assistance from pre-COVID projects, with nearly half (46\%) supported by the government. However, 30\% reported that they had received no assistance from any source. Generally, there were no significant changes in household caring responsibilities since the start of the crisis.

\section{Availability of services for agricultural production}

Slightly more than half of respondents reported no change in the availability of land for rent and farm inputs. However, costs had escalated for close to $40 \%$ of participants since the crisis began. 
They also reported a significant decline in the availability of extension services and $70 \%$ mentioned a lack of credit facilities, which is likely to affect the outcome of the upcoming 2020/21 farming season.

\section{Food and nutrition security since COVID began}

\begin{tabular}{|l|c|}
\hline Aspect & Proportion (\%) \\
\hline Worried about inadequate food & 76 \\
\hline Unable to eat healthy foods & 78 \\
\hline Ate only a few food types & 78 \\
\hline Skipped meals & 57 \\
\hline Ate less & 70 \\
\hline Ran out of food & 54 \\
\hline Hungry but no food to eat & 48 \\
\hline No eating for the whole day & 31 \\
\hline Food not adequate for family & 75 \\
\hline
\end{tabular}

- $\quad$ About $31 \%$ of respondents reported spending an entire day without eating due to lack of money and other resources.

- $\quad$ COVID-19 is not wholly responsible for food insecurity as the pandemic came during harvest period and farming was not disturbed significantly. However, it may well disrupt the 2020/21 farming season.

- Food availability and prices in local markets were reported to remain largely unchanged.

- However, half of sample households reported experiencing an increase in the overall cost of living.

- Respondents were also asked to give an assessment of their overall welfare situation before and after COVID-19 using a 9-step ladder approach. The proportion who stated they are 'unable to change their lives' at the bottom of the ladder was found to have increased.

\section{Farming, labour and marketing}

- About $60 \%$ reported a decline in business activities.

- $\quad$ Farming activities saw no change due to COVID-19 possibly because the season just ended.

- Access to off-farm work was limited at $44 \%$ and $24 \%$ within and outside the village, respectively.

- Only $16 \%$ of those seeking to hire farm labour were able to do so.

- Nearly three-quarters (65\%) reported a decline in the sale of produce both at the farm gate and in local markets.

- Hiring of transport to a point of sale was a problem for $72 \%$ of respondents with increasing costs due to COVID-19.

- The presence of traders in communities had declined.

- $\quad$ Cash remained the main payment mode.
Changes in activities and costs

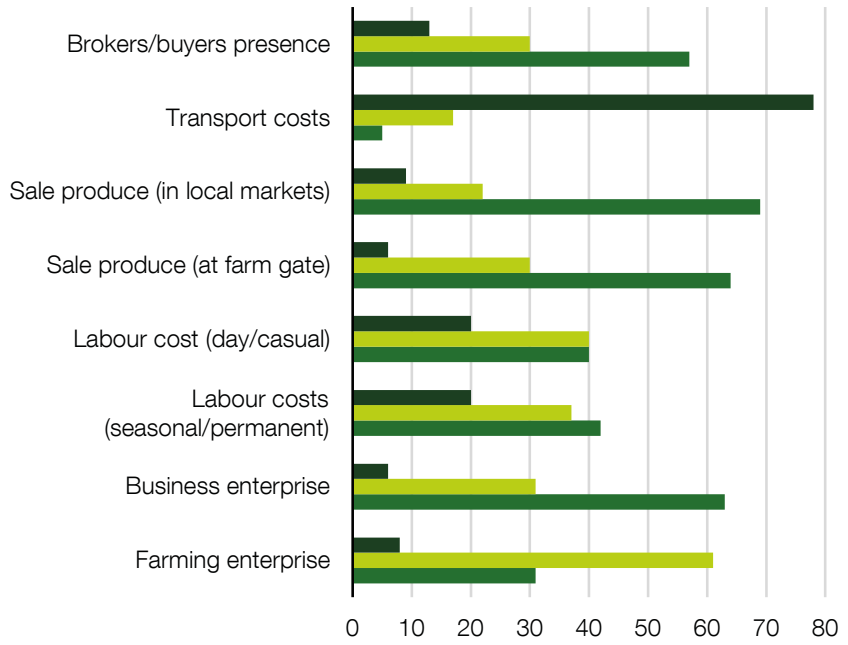

- Increased No change $\square$ Decreased

This is an Open Access report distributed under the terms of the Creative Commons Attribution Non Commercial No Derivatives 4.0 International licence (CC BY-NC-ND), which permits use and distribution in any medium, provided the original authors and source are credited, the work is not used for commercial purposes, and no modifications or adaptations are made.

If you use the work, we ask that you reference the APRA website (www.future-agricultures.org/apra/) and send a copy of the work or a link to its use online to the following address for our archive: APRA, Future Agricultures, University of Sussex, Brighton BN1 9RE, UK (apra@ids.ac.uk) 